This paper has been accepted for publication in the Journal of Religious History. The definitive version is available at www.interscience.wiley.com.

\title{
Catholic responses to evolution, 1859-2009: local influences and mid-scale patterns
}

\section{Introduction}

In his influential book, Science and religion. Some historical perspectives, John Brooke convincingly argued that, within the history of science and religion, grand narratives can be no longer defended. ${ }^{1}$ In particular, the popular image of a continuous war between these two cultural domains fails to reflect what has actually occurred and still occurs. There exists no general negative religious response to a unified corpus of scientific knowledge. Instead, through modern historical research a variety of religious responses has emerged. ${ }^{2}$ These reactions were often directed at particular (interpretations of) scientific issues or discussions, but not science in general. Therefore, at both sides, the historical relation between science and religion has become increasingly complex. ${ }^{3}$

With this paper I intend to establish whether, historically, Catholic responses to evolution and evolutionary theory ${ }^{4}$ reveal a similar level of complexity. A quick look at the contemporary debate about scientific creationism and Intelligent Design (ID), suggests such an approach is at least viable. It discloses a wide range of Catholic attitudes, from strong sympathy for scientific creationism ${ }^{5}$, to a radical defence of ID $^{6}$, to a full acceptance of evolutionary theory (and an according rejection of any antievolutionary position) ${ }^{7}$. Notwithstanding the fact that some of these opinions form only a minority position, they do point towards a certain flexibility in Catholic orthodoxy. If we can indeed ascertain that Catholic responses to evolution are complex, we can expect that local factors, in parallel with their significance in 
Protestant reactions to evolution ${ }^{8}$, were involved. However, the idea that we need to abandon grand historical narratives does not imply that we need to stop looking for general trends or “mid-scale patterns", by which we can simplify the historical complexity. ${ }^{9}$

In order to discern both the significance of local factors and the occurrence of common patterns, I have opted to focus primarily on secondary literature. This approach creates the unique opportunity to compare the Catholic reception of evolution across different national settings, which will here constitute the local contexts. So, in contrast with Livingstone's approach, who studied the impact of local factors at the communal level, I will speak here of local factors at the national level. However, in the end, both cases study how the historical relation between science and religion is mediated by contextual factors, which renders grand narratives concerning this relation, at least historically, indefensible.

First, I will discuss how the Vatican initially responded to evolution, more specifically in the period between 1859, the year in which Darwin published his seminal volume On the origin of species, and 1907, the year in which Pope Pius X issued the encyclical Pascendi dominici gregis in condemnation of the modernist movement within the Church. Next, I will explore how Catholic intellectuals and communities dealt with evolution. Particularly in this section, I will identify the local factors that influenced their responses and explain how they did so; but I will also demonstrate that, gradually, Catholics shifted towards a more relaxed position concerning evolution. I will thereby not make a sustained comparison between several local or national settings, from which the impact of several factors can be deduced. Rather, I have selected samples from the literature that either discuss the impact of particular local factors in a particular local setting or that most aptly illustrate the impact of some local factor and/or a midscale pattern. The samples include discussions of Catholic responses in the US, France, Belgium, the Netherlands, Ireland, Spain and Italy. The focus lies on responses in Europe and 
the US, because these are more intensively discussed, and thus more widely available, in the historical literature. Thirdly, I will briefly demonstrate that, in the end and somewhat hesitantly and conditionally, the Vatican gradually became more receptive of evolutionary sciences.

\section{Early Vatican responses to evolutionary theory, 1859-1907}

The history of Protestantism has seen many schisms and sudden appearances of new cults and churches. Because of the resulting plethora of denominations, it is not very surprising to find that Protestant reactions to evolutionary theory have varied widely, thus indeed establishing the complex pattern that Brooke and others have discerned. ${ }^{10}$ The Catholic Church, in contrast, is characterized by a hierarchical structure, in which the doctrine of Catholic faith is monopolized and carefully guarded by the Holy See in Rome. Catholics, however, have been as creative as Protestants in responding to the intellectual and religious challenges posed by evolution. Thus, at the least, some Catholics had the impression they were allowed some freedom to formulate their own position concerning this issue.

This impression was in no small part caused by the extreme caution by which the Vatican itself treated the matter of evolution. Having experienced serious embarrassment after the Galilei case (in which the Church had put Galilei's work on the Index in 1633), the Vatican opted to abstain from formulating any official statement on yet another unsettling development in modern science. ${ }^{11}$ Instead, it resorted to a more "pragmatic policy", dealing with evolutionary ideas and writings on a case-to-case basis. ${ }^{12}$ Between 1870 and 1925, the outcome of these cases was generally not in favour of the attempts made by clergymen, theologians and Catholic scientists to reconcile evolution with Catholic faith. But the message the Vatican tried to convey came across far less strongly than if it had done so through a public condemnation. Of the six cases Artigas and his colleagues discuss in their book 
Negotiating Darwin, there is only one case in which a publication, a book written by Rafaello Caverni, was put on the Index for its pro-evolutionary views. ${ }^{13}$ This sanction was expressly intended as a warning for others to steer clear of evolution-friendly ideas. However, because books were put on the Index without stating the reason why, this signal was to no avail. Later, authors were asked to publicly retract their publications instead. This offered them the opportunity to avoid a public condemnation of their work, whereas, for the Vatican, these retractions had the advantage of including an explanation as to why the work was being retracted. However, Catholic proponents of evolution only took home the message that they should proceed with care, not that they should not proceed at all. As a result, the Vatican was incapable of putting an end to the production of evolutionary writings.

Nevertheless, the Vatican's antagonism towards evolution lasted well into the 1920s. This was not so much because evolution seemed inconsistent with a literal interpretation of the Bible, more particularly of the book of Genesis, but because evolutionary theory, especially Darwin's formulation of it, seemed to threaten certain tenets of Catholic doctrine, in particular, the special creation of man. ${ }^{14}$ However, it should be noted that even the Catholic intellectuals who sought to harmonize their faith with evolution did not go as far as to question the divine origin of the human soul or the creation of the first woman out of the first man's body. They only proposed that the first man's body could have been somehow prepared though an evolutionary process that was guided by God. For the traditionalists in the Vatican, however, even this minimal concession was a bridge too far. To them, Catholic doctrine clearly held that man was the direct result of God's work, in both his soul and his body.

Another reason why the Vatican opposed evolution was the widespread association of evolution with atheism and materialism. Indeed, all across Europe proponents of both schools of thought had easily incorporated evolution in support of their ideas. They hailed Darwin as 
the scientist who had irrefutably demonstrated that all life, including human life, was the contingent outcome of natural processes. Under such an interpretation, of course, the Church could not possibly embrace evolutionary science. Theistic evolutionists shared the idea that evolution had become closely linked with materialism and atheism, but, instead, they insisted that this connection did not obtain necessarily. Once they disconnected evolution from these unwelcome alliances, Catholics could accept evolution without abandoning their faith. However, these individuals could not change the adverse current within the Vatican for a long time. The influence of the traditionalist parties within the Church simply proved too strong.

The traditionalist stance on the interpretation of Catholic dogma and on evolution was zealously propagated by the authors of La Civiltà Cattolica $(C C)$, the Jesuit periodical that first appeared in April 1850 under the encouragement of Pope Pius IX. Although recently there has been some discussion as to the exact role $C C$ played during the second half of the nineteenth century in shaping the Vatican's attitude towards evolution, $C C$ is generally recognized to have had "a certain authority" due to its "special relationship with the Holy See". ${ }^{15}$ Since $1860, C C$ regularly published articles expounding strident anti-evolutionary positions and acrid reviews of pro-evolutionary works written by fellow Catholics. By the turn of the twentieth century, when evolution gained appeal among Catholic intellectuals, $C C$ boosted its production of antievolutionary writings, and also eagerly republished the retractions made by pro-evolutionary authors in other journals. As such, $C C$ helped fabricating and uncompromisingly communicated the message that the Church heartily disapproved of any attempt to reconcile the Catholic faith with evolution. However, $C C$ never functioned as the Church's official organ, nor did it succeed in extracting an official condemnation of evolution from the Holy See. ${ }^{16}$ Instead, $C C$ had to be satisfied with the condemnation of other issues that could be considered to be related to evolution, but not 
necessarily so. Hence, theistic evolutionists could just as easily avoid the anti-evolutionary conclusions the authors of $C C$ and their co-traditionalists were keen on drawing.

The only explicit statement made by a Catholic authority on the issue of evolution before 1950 can be found in the decrees that were drafted after the provincial Council of Cologne, held in $1860 .{ }^{17}$ Although the Vatican officially approved of these documents, they should not be understood as conveying any position of the Church. As the council's authority was restricted to the diocese of Cologne only, it lacked the hierarchical power to issue such documents. Nevertheless, its assessment of evolutionary theory in relation to the interpretation of the book of Genesis and Catholic faith foreshadowed the position that gleamed through the later Vatican policy, not only in its content, but also in its intent to send a clear warning against evolutionary teachings and its consequent failure to do so. The words of the decree read: "The first parents were created directly by God. Therefore, we declare as contrary to Sacred Scripture and to the faith the opinion of those who are not ashamed to assert that man, insofar as his body is concerned, came to be by a spontaneous change from imperfect nature to the most perfect and, in continuous process, finally human." ${ }^{\prime 18}$ At first sight, these words seem to reject evolution altogether. However, it only condemns "spontaneous change", not evolutionary change per se. The decree could therefore be just as easily and sensibly interpreted to allow for an evolutionary process guided by God. This kind of confusion on how to interpret the Church's actions and official documents became a recurrent theme in Catholics' attitude towards evolution. The Church's enduring hesitance to speak out definitively on the topic of evolution fuelled this ambivalence, creating the ideal environment for alternative opinions to emerge.

The Holy See, however, was not always so hesitant in condemning issues it considered a threat to Catholic orthodoxy. By the end of the nineteenth century the Church faced one of its 
greatest challenges ever, a movement that developed within its own ranks, called modernism. As 'modernism' covered a wide range of opinions and soon turned into the metaphorical stick to beat a dog with, the term is hard to define in great detail. ${ }^{19}$ However, it commonly refers to a group of scholars that "adopted a critical and skeptical attitude toward the traditional doctrines of their church." ${ }^{20}$ In a genuine attempt to attune Catholic faith to the intellectual demands of modern times. they brought the methods of historical research and the natural sciences to bear on the interpretation of the Bible and Catholic dogma. This approach, however, contrasted sharply with the revival of neo-Thomism in Catholic thought, instigated by Pope Leo XIII through the encyclical Aeterni Patris (1879). Neo-Thomism, which was primarily based on the works of the medieval theologian Thomas of Aquino, was intended to bridge Catholic faith and modern science. In effect, this "synthesis" boiled down to moulding scientific findings into the preset framework of Catholic dogma. ${ }^{21}$ Modernists, however, maintained that the dogmas themselves had evolved. Unsurprisingly, the Vatican regarded modernism as one of the biggest evils of all time, and battled it in a fierce campaign that did not cease until the second Vatican Council, well into the twentieth century. One important step in this campaign was the publication of the encyclical Pascendi Dominici Gregis (1907), in which pope Pius $\mathrm{X}$ in no uncertain terms denounced modernism as "the synthesis of all heresies". The encyclical also included passages that were clearly intended to target evolutionary thought as part of the modernist heresy, but again, because of the indirect approach, it failed to get the message through. ${ }^{22}$ For instance, at the Catholic University of Louvain in Belgium, a group of progressive Catholic intellectuals did not interpret the encyclical in that sense and continued their efforts to reconcile their faith with evolution. ${ }^{23}$

Americanism was another phenomenon the Church had to deal with. As the very name suggests, the movement originated within the Church in the United States. It grew out of the 
continuous efforts by liberal Catholics to help the fast-growing masses of Catholic immigrants from all over the world, accommodate to the specifics of the North American cultural context. ${ }^{24}$ Americanists were in favour of the separation between State and Church, which is inscribed in the US Constitution, and argued for more individual liberty in dealing with religious questions. $^{25}$ This atypical emphasis on individualism increasingly worried traditionalists both in the United States and in Rome, especially when the movement became popular in France, a country which had already become highly secularized after the revolution in 1789. According to the traditionalists, Americanism equated with Protestantism, which prompted Pope Leo XIII in 1899 to write a letter called Testem Benevolentiae to the archbishop of Baltimore, in which he condemned Americanism as unorthodox.

Americanism was deeply associated with evolutionism. In 1896, John Zahm, a prominent Catholic priest who was considered a member of the Americanist movement, published a book called Evolution and Dogma, in which he claimed that evolution, including the evolution of the human body, did not oppose Catholic orthodoxy. Zahm also argued that both St.Augustine and Thomas of Aquino were evolutionists. The book was soon translated into French and Italian and became highly popular in both the US and Europe, but not in Rome. ${ }^{26}$ $C C$, published a highly critical review, which the traditionalists consequently used to have Zahm's book condemned and consequently prohibited. Privately, Zahm immediately submitted to the decree, but, due to efforts of himself and his supporters, nor the decree, nor his submission became published. ${ }^{27}$ The traditionalists had to be satisfied with the publication - without Zahm's consent - of a letter he had written to his publisher in Italy in which he asked him to withdraw the Italian translation of his work. ${ }^{28}$ However, both Leo XIII's letter and the actions against Zahm's work failed to send a clear message. Although the Church 
clearly did not favour evolution, pro-evolutionary Catholic intellectuals did not conclude that the Vatican conceived of their ideas as unorthodox.

\section{Catholics respond to evolutionary theory, 1859-1950}

As suggested above, not all Catholics shared the Vatican's negative attitude towards evolution. ${ }^{29}$ Naturally, many of them found it difficult to embrace a concept that, prima facie, fuelled several non- and even anti-religious ideologies and, therefore, flew in the face of some of their most cherished beliefs. They were primarily concerned with the idea that humans had evolved from a simian ancestor through a purely natural process, called natural selection. As a result, most Catholics renounced the theory, especially during the first two decades after the publication of On the origin of species in 1859. However, the Vatican's adverse but hesitant stance on the matter was but one of the factors that had an impact on Catholics' appreciation of evolutionary theory.

Another influential factor was the way in which evolution was presented and by whom. This key element has been well documented by Livingstone. ${ }^{30}$ In his research on the differential reception of Darwinism in the three Presbyterian communities of Belfast, Edinburgh, and Princeton, New Jersey, he shows that the most ardent opposition arose in Belfast where evolution had been introduced to the faithful through the address John Tyndall had delivered in 1874 at a local meeting of the British Association for the Advancement of Science (BAAA). Tyndall highlighted the antireligious implications of Darwinian theory, thereby provoking a strong religious reaction among the local Calvinist community. However, because of Tyndall's address, Irish Catholics too immediately associated evolutionism with atheism and consequently resented it, an attitude that would hardly change until after the second World War. ${ }^{31}$ 
However, when evolutionists presented their views as compatible with Catholic faith, it met with much less adversity. In Belgium, for instance, evolution had been introduced a couple of decades before Darwin had written his Origin. Jean d'Omalius Halloy (1783-1875), a respected geologist and an eminent figure in the Belgian scientific establishment during the first three quarters of the nineteenth century, defended a kind of spiritual evolutionism - with humans clearly distinct from the rest of creation - that he thought could encompass both evolution and Catholicism. His version of evolution did not engender any fierce rejection of or opposition to evolution from Belgian Catholics. They did not endorse d'Omalius views they presumably did not - but they simply remained silent on the issue. ${ }^{32}$ With no threatening formulation of evolutionary thought to deal with, there simply was no need for an outspoken reaction. Belgium was not the only country where evolutionary theory was initially received with relative silence. ${ }^{33}$ Similarly, in its neighbouring country, the Netherlands, the Catholic community did not express a strong opinion on evolution until the late 1860 s. There too, scientists introduced evolution - again, before the arrival of Darwinian theory - as a concept reconcilable with Christian faith. ${ }^{34}$ Instead, evolution was caught up in a theological discussion about the existence of miracles and in the philosophical discussion about the nature and appropriate methods of science. These rather academic discussions among Protestant theologians and among scientists, had no real or direct impact on the beliefs of the common Catholic. ${ }^{35}$ However, in 1868, Karl Vogt, a renowned German materialist and a co-worker of Ernst Haeckel, delivered a series of lectures in Rotterdam in one of which he discussed the primate ancestry of humans. Both Dutch Catholics and Protestants considered this unacceptable, but it was mainly the former who reacted with an outburst of antievolutionary writings that shaped the opinion for decades to come. ${ }^{36}$ In the Netherlands, more nuanced Catholic voices could not be heard until the beginning of the twentieth century, and 
evolutionary theory remained suspect until the $1960 \mathrm{~s} .{ }^{37}$ This was long after Dutch liberal and even some orthodox - Protestants had made their peace with evolutionary science.

Political struggles also had an impact on Catholic responses. For instance, in Spain, censorship and limited educational freedom halted the dissemination of evolutionary thought until the revolution of 1868 when the monarchy was replaced by a republic government. ${ }^{38}$ Consequently, Spanish Catholics, ranging from “exegetical anti-Darwinists", over "learned hardliners" to "a small group of Catholic scientists and ecclesiastics who sought to harmonize the two positions", opposed evolution because they associated it with revolutionary materialist ideologies. ${ }^{39}$ And indeed, liberal intellectuals and reformers considered evolution to constitute a crucial aspect of their ideological position. As Thomas Glick put it: "In the debate between the 'two Spains', liberal and conservative, modern and traditional, Darwinism was a touchstone." 40

Evidently, the debates on evolution were hardly ever restricted to purely scientific arguments. Not only did evolution become easily associated by both Catholics and evolutionists with materialistic, atheist ideologies, but evolution also became easily entwined with local political, sociological or philosophical discussions. In the Netherlands, evolution was initially incorporated into the local and rather moderate theological and philosophical discussions over miracles and the nature of science. In the US, evolutionism was embraced by the liberal clergy within the Americanist movement, whereas traditionalist parties sided with the disapproving position of the Vatican, a tension epitomized by the Zahm case. However, the debates over Americanism were also of a practical nature, particularly about how to deal with the Catholic immigrant communities that arrived in the United States. ${ }^{41}$ Internationally, evolution became a major issue during the modernist crisis, thereby becoming highly significant for the delineation of Catholic orthodoxy. ${ }^{42}$ The higher the stakes of the debate - 
and in the case of modernism they were extremely high - the more intense the debate on evolution became and the more weight non-scientific arguments acquired.

However, the fact that other issues were involved in the discussions surrounding evolution does not mean that scientific arguments were entirely absent. Both pro- and antievolutionary sides referred frequently to contemporary scientific findings and arguments to bolster their positions. In France, for instance, Catholic intellectuals pointed out repeatedly that the national scientific community opined that evolutionary theory bore too many deficiencies to be regarded as proper science. Indeed, most French scientists considered themselves to be positivists and argued that Darwin's theory relied too much on idle speculation and too little on rigorous observation and experiments. ${ }^{43}$ Elsewhere, opponents of evolution, in particular of the Darwinian variety, had no trouble in finding genuine, scientific ammunition to fire up their attacks. Although most biologists had come to accept the fact of evolution within a decade, they had more trouble coming to terms with the mechanism of natural selection. Multiple alleged difficulties with the theory undermined the explanatory power of the concept: there were too few fossils to illustrate a gradual change from one species into another; the physicist William Thomson, better known as Lord Kelvin, had calculated that the age of the Earth did not allow for (the slow, gradual process of) natural selection to bring about biological complexity. Moreover, Darwin did not provide a satisfying theory of how heritable characteristics of organisms were preserved and passed on from generation to generation. Starting in the 1870 s, these criticisms amounted to a period in which alternative evolutionary theories such as neo-Lamarckism, orthogenesis and saltationism ${ }^{44}$, almost entirely overshadowed natural selection. ${ }^{45}$ Naturally, religiously inspired opponents of Darwin's theory did not hesitate to invoke these scientific arguments. 
Because the scientific community did not readily accept natural selection, more liberal believers were granted the intellectual space they needed in order to reconcile their faith with evolution. However, in the Origin, Darwin himself hinted at a possible solution for the conflict between his theory and belief in God. ${ }^{46} \mathrm{He}$ surmised that God could have initiated the law of natural selection, just as he had set in the laws of physics and then let these laws do their intended work. Elsewhere, Darwin complained about the fact that people felt the need to invoke a designer in the case of natural selection whereas Newton's law of gravity did not ignite such a response. To his friend, the famous geologist Charles Lyell, he wrote: "No astronomer in showing how movements of planets are due to gravity, thinks it necessary to say that the law of gravity was designed that the planets should pursue the courses which they pursue." And he added: "I cannot believe that there is a bit more interference by the Creator in the construction of each species, than in the course of the planets."47 For a Catholic, however, who was bound to the teachings of the Church, Darwin's attempt at reconciliation would have been less than satisfactory. In particular, Catholic evolutionists consistently made an exception for the divine creation of the human soul. ${ }^{48}$ Furthermore, in accordance with the prevailing philosophy of neo-Thomism, evolution was regarded as a teleological process, with a divine intelligence determining its track. As such, God's role in creation had to be more active than Darwin imagined. And finally, Catholic evolutionists were careful to present their reconciling efforts as provisional theories. The truth of the evolutionary hypothesis, they conceded, was far from established. By observing these particular rules, Catholic evolutionists thought they did not transgress the borders of orthodoxy.

This adapted form of evolutionism developed only after Catholic intellectuals had become sufficiently acquainted with evolutionary science. Once they were convinced of the fact of evolution, they realized that, if Catholics were ever to embrace the new science, they had to 
pry evolution from the hands of materialists and atheists. Ironically, the Church itself had promoted science education to counteract the imperialistic claims that its ideological enemies had laid to science. If Catholics were to argue on a par with their opponents, they had to become more scientifically literate. After all, according to Catholic teaching, the Church had nothing to fear: truth could never contradict truth, and therefore, true science had to be in line with Catholic faith. Neo-Thomism, which revived the teachings of the medieval theologian Thomas Aquinas, served as the foundation upon which the reconciliation of Catholic faith and modern science was to be established. Especially in Europe, several Catholic institutions were founded, the members of which published their works in newly established journals. ${ }^{49}$ However, as the Catholic intelligentsia indeed became more scientifically informed, evolution inevitably became part and parcel of their intellectual baggage and was consequently perceived as less threatening.

Several historical examples document the effect of science education and scientific information on the acceptance of evolution by Catholics. First, between 1888 and 1900, there were five international conferences at which Catholic scientists not only presented their recent work, but also discussed the latest scientific findings in general, including evolutionary science. At the first conference in Paris, a proposition that stated that evolution ran counter to faith and scripture was submitted in the anthropology session. The motion was not accepted, but still evolution was not considered a fact, but a useful hypothesis that should be freely discussed. Six years later, at the third conference in 1894, held in Brussels, Catholic scientists felt more confident about the status of evolution and accepted a declaration that sought to actively promote the study of evolution. By the fifth and last conference, in 1900, the Catholic scientists took evolution for granted as they did not discuss the issue anymore. ${ }^{50}$ The best 
scientifically informed Catholics had come to endorse evolution. However, for the Church at large the issue was far from resolved.

Secondly, the impact of education becomes all the more apparent when we compare the responses of Catholics in different countries. In Belgium, for instance, the Société scientifique de Bruxelles was founded in $1875 .{ }^{51}$ Consequently, two journals were published, the Annales de la société scientifique de Bruxelles in 1875 and the widely read Revue des questions scientifiques in 1877. Remarkably, Jesuits were deeply involved in these developments: Ignace Carbonelle had taken the initiative in founding the Société, and shortly thereafter, his colleagues took the lead in the Société in defending the possibility of Catholic evolutionism in Belgium. ${ }^{52}$ Eventually, around 1900 , this positive attitude towards evolution took root in the Catholic University of Louvain, where a group of progressive intellectuals supported the compatibility of faith and evolution, both in their lectures and their publications. Some even defended their evolutionism through popular addresses, thus introducing evolution to a wider public and promoting its dissemination. By the 1930s, Belgian Catholic intellectuals increasingly accepted evolution. ${ }^{53}$ In the Netherlands, however, before 1900, Catholics preferred to protect themselves and their community from the perceived threats of modern science. The Society for the Advancement of Science among Catholics was only founded in 1904, almost thirty years after the Société in Brussels. The first Dutch Catholic university was only established in 1923 in Nijmegen containing faculties of Theology, Arts and Law, but not of Science. As a result, the introduction of evolutionary thought into Dutch Catholic circles took more time than in Belgium and opposition to evolution abated more slowly. ${ }^{54}$

To sum up, local factors did exert considerable influence on the way Catholics approached the issue of evolution. Questions such as who represented or taught evolution, what other ideas was it associated with, in which local debates it became entrenched, and the level of science 
education should all be taken into account, leading indeed to a complex picture, just like Brooke's analysis suggests. However, it appears that these factors did not so much steer the Catholic assessment of evolution, but rather that in some cases they catalyzed or in others slowed down a process that, historically, can be discerned among Catholics in general. The result is that, in the end, the majority of Catholic intellectuals - but certainly not all gradually came to accept evolution; some even accepted evolution by natural selection and considered it compatible with their faith. Therefore, we can discern at least one pattern, a pattern of reconciliation, that, as Numbers puts it, simplifies the complexity. Whether this pattern is due to the relatively higher significance of international over local factors, to the particular hierarchical structure of the Catholic Church, or to the inherent character of Catholic dogma, is an important question, but one we cannot answer here.

In the end, even the Vatican complied with the pattern. For decades, the Vatican tried to block the dissemination of evolutionary thought among its flock. But, without an official decree in which it condemned evolutionism it could never really put a halt to the flow of increasingly popular writings in which Catholics defended the compatibility of Catholic orthodoxy and evolution. Until 1930, the Church remained skeptical of these attempts, but later, the Vatican started to take on a more lenient attitude, leading up to a first official document discussing evolution in 1950. In the next and final section, we will briefly discuss how the Church eventually and gradually came to terms with evolution.

\section{Vatican responses to evolutionary theory, 1907-2009}

When in 1909, the Belgian Catholic geologist Henri De Dorlodot accepted the invitation to represent the Catholic University of Louvain at the centennial Darwin commemorations in Cambridge, the scientific community interpreted this as a sign of the Catholic world finally coming to terms with evolutionary theory. ${ }^{55}$ But this conclusion was premature, as De 
Dorlodot would later experience himself. In 1918, he published his volume, Le darwinisme au point de vue de l'orthodoxie catholique, in which he asserted that he intended to protect Catholic orthodoxy from the aberration of fixism that had reduced God to a tinkering fool. Evolution was a fact, and Catholics should not have no doubts about accepting it. Even the evolution of the human body was an inescapable, but also orthodox conclusion. This radical book was later translated into English by Ernest Messenger and received a warm welcome in the American Catholic press. One commentator even felt that the affirmative attitude taken by De Dorlodot could be understood as reflecting the official position of the Church, but he was mistaken. Inevitably, De Dorlodot's book drew the attention of the traditionalists who threatened him with an official condemnation. In the end, however, the "Dorlodot affaire" ended on an "uncomfortable status quo"56: On the one hand, De Dorlodot, who died in 1929, never published on the issue of evolution again. After the "affaire", he felt compelled to abandon his plans to publish a second volume on evolution and never replied to the requests for a German translation of his first volume. ${ }^{57}$ On the other hand, he never officially retracted his work. The fact that De Dorlodot did not receive any reprimand, indicated that the power of the traditionalists had started to wane. ${ }^{58}$ After the De Dorlodot affair, in 1926, Teilhard de Chardin, the famous French Jesuit paleontologist, was proscribed by his superiors from teaching and publishing any longer on the issue of evolution and was sent for two years to China. However, after this incident, it seemed that the hierarchical powers became increasingly tolerant towards evolutionary thinking. In 1925, French catholic scientists, who had organized an international meeting to discuss evolution at Altamira, sent a document to Pope Pius XI, in which they stated that evolution was an important scientific concept and did not oppose Catholic doctrine, an initiative to which Pius responded with sympathy. ${ }^{59}$ Furthermore, when in 1932 Ernest C. Messenger published his work, Evolution and theology. The problem of man's origin, in which he argued for the compatibility of Catholic faith with 
evolution, he met with only a few adverse reactions. Eighteen years later, the message of this book resonated within Humani Generis (1950), the encyclical in which Pope Pius XII finally addressed the issue of evolution. ${ }^{60}$ However, in the interwar period, the majority of Catholics still did not accept evolution. ${ }^{61}$

In Humani Generis, Pius XII conceded that the evolutionary origin of the human body offers an interesting hypothesis that Catholics can explore. However, the pope hastened to add that the hypothesis was far from proven. He declared:

Some however, rashly transgress this liberty of discussion, when they act as if the origin of the human body from pre-existing and living matter were already completely certain and proved by the facts which have been discovered up to now and by reasoning on those facts, and as if there were nothing in the sources of divine revelation which demands the greatest moderation and caution in this question. ${ }^{62}$

This passage illustrates that the Vatican still had difficulties with an evolutionary account of human origins, even after many members of its Church had long come to accept it. It took almost another fifty years, before Pope John-Paul II in his address to the Pontifical Academy of Sciences on 22 October 1996 would admit that evolutionary theory was "more than a hypothesis". This had become possible after the Second Vatican Council (1962-1965) had created an environment charitable to the theories of Catholic evolutionists, in particular those of the late Teilhard de Chardin, who had been silenced by the Vatican in the 1910s and 1920s, but whose writings had become highly popular in Catholic intellectual circles. ${ }^{63}$ The address was hailed widely as the definite statement of the acceptance of evolution by the Catholic world. However, Pope John-Paul II maintained that the human soul, the essence that makes humans distinctively human, could only be explained in terms of "an ontological leap", and proved to remain very skeptical towards evolutionary approaches to the human mind. ${ }^{64}$ In 
Communion and Stewardship: Human persons created in the image of God, published in 2004, the International Theological Commission, under the chairmanship of Cardinal Joseph Ratzinger declared that "even the outcome of a truly contingent natural process can nonetheless fall within God's providential plan for creation",65, which suggests that even a purely naturalistic account of evolutionary processes is considered compatible with Catholic doctrine. Nevertheless, it is argued that "Catholic theology affirms that that the emergence of the first members of the human species (whether as individuals or in populations) represents an event that is not susceptible of a purely natural explanation and which can appropriately be attributed to divine intervention." 66

In Autumn 2008, the Pontifical Academy of Sciences organized a conference in the Vatican to discuss Scientific insights into the evolution of the universe of life. In his address to the Academy, Pope Benedict XVI referred to his predecessors' view that faith and science did not contradict one another, but he did not provide a clear statement in support of evolution or evolutionary theory. ${ }^{67}$ Moreover, Cardinal Schönborn caused a small incident by suggesting that" the theory of evolution still has its gaps which it should not make light of." ${ }^{68} \mathrm{He}$ also claimed that " $[\mathrm{t}[$ he understanding of the origin of intelligence, in the evolutionary intelligence theory, sociobiology, evolutionary ethics, all these fields are limiting to a model of evolution that is taken from a scientific theory which is probably overexpanded beyond its true limits." However, morality and intelligence have come increasingly under the scope of evolutionary informed research in anthropology, psychology and other social sciences. To conclude, the Church has indeed given a strong impression that it has come to terms with evolution and even evolutionary theory. However, certain aspects of modern evolutionary theory, in particular its implications for understanding human intelligence and morality, often remain hard to accept for Catholic authorities, spokesmen, and theologians, which they either discard 
as "philosophy" or as unwarranted extensions of an aggressively asserted, but still controversial (and immoral) theory. ${ }^{70}$

\section{Conclusions}

Today, Catholic opinion makers, intellectuals and prominent members of the Church regularly call for a rational dialogue between science and religion, thereby distancing themselves from the antievolutionism they associate with orthodox and fundamentalist strains of Protestantism. This review has clearly demonstrated that the Catholic Church has not always promoted such a dialogue, in particular regarding evolution. After the publication of On the origin of species in 1859 , the Vatican opposed evolution for almost a century. It did so through a pragmatic policy, dealing with evolutionary writings on a case-to-case basis and by condemning issues like modernism and Americanism that it considered entangled with evolution. But, anxious to avoid yet another humiliation after the Galileo affair, the Vatican never officially condemned evolution itself. This prudent modus operandi proved insufficient to halt the increasing output of publications that argued for the reconciliation of evolution and catholic faith. The common initial response of Catholics, if they reacted at all, had often been hostile, but, because of its growing attraction and popularity, Catholic intellectuals gradually grew increasingly relaxed with evolution. This review of the secondary literature suggests that this process seems to constitute a general pattern across many European countries and the US, but that the pace at which the process occurred was nevertheless highly influenced by local factors, such as the way in which evolution was presented and the level of science education of the Catholics who responded to evolution. Today, the Vatican too seems to have adopted a conciliatory attitude towards evolution and evolutionary theory as it even hosted conferences at which scientists and theologians freely discussed these issues. Some aspects of modern evolutionary theory, 
however, in particular relating to the evolution of human morality and intelligence, are still difficult to accept.

\section{Acknowledgments}

The research for this article was supported by grant BOF08/24J/041 from Ghent University. The author would like to thank Maarten Boudry, Johan Braeckman, Abraham C. Flipse, Barbara Forrest, Ronald Numbers, Sarah Van Ruyskensvelde and the anonymous reviewers for their helpful remarks.

\footnotetext{
${ }^{1}$ John Hedley Brooke, Science and Religion : Some Historical Perspectives, Cambridge History of Science (Cambridge: Cambridge University Press, 1991), 52.

${ }^{2}$ David N. Livingstone, "Evolution and Religion," in Evolution. The First Four Billion Years, edited by Michael Ruse and Joseph Travis (Cambridge, MA: Belknap Press of Harvard University Press, 2009), 348-69.

${ }^{3}$ This contribution of Brooke to the historiography of science and religion boils down to what Ronald Numbers has dubbed the "complexity thesis" Ronald L. Numbers, "Simplifying Complexity: Patterns in the History of Science and Religion," in Science and Religion. New Historical Perspectives, edited by Thomas Dixon, Geoffrey Cantor, and Stephen Pumfrey (Cambridge: Cambridge University Press, 2010), 263-82.

${ }^{4}$ I will here employ the terms "evolutionary theory" and "evolution" consistently in clearly distinct ways. Evolutionary theory denotes the scientific theory, i.e. the explanation,, of evolution by natural selection, sexual selection and genetic drift. Evolution merely denotes "evolutionary process". Therefore one can accept
} 
evolution, without necessarily accepting evolutionary theory. I have avoided the term "Darwinism" altogether because of its ambiguity and its ideological overtones.

${ }^{5}$ Brian W. Harrison, "Early Vatican Responses to Evolutionist Theology," Living tradition. Organ of the Roman theological forum, no. 93 (2001), http://www.rtforum.org/lt/lt93.html.

${ }^{6}$ Michael J. Behe, Darwin's Black Box : The Biochemical Challenge to Evolution (New York: Free Press, 1996).

${ }^{7}$ Kenneth R. Miller, Finding Darwin's God. A Scientist's Search for Common Ground between God and Evolution (New York: HarperCollins, 1999).

${ }^{8}$ David N. Livingstone, "Science, Region, and Religion: The Reception of Darwinism in Princeton, Belfast, and Edinburgh," in Disseminating Darwinism. The Role of Place, Race, Religion, and Gender, edited by Ronald L. Numbers and John Stenhouse (Cambridge: Cambridge University Press, 1999), 7-38.

${ }^{9}$ Ronald L. Numbers, "Simplifying Complexity: Patterns in the History of Science and Religion,” 264.

${ }^{10}$ For a discussion of a variety of Protestant reactions to evolutionary theory in the $19^{\text {th }}$ century, see e.g. James Richard Moore, The Post-Darwinian Controversies : A Study of the Protestant Struggle to Come to Terms with Darwin in Great Britain and America, 1870-1900 (Cambridge ; New York: Cambridge University Press, 1979), David N. Livingstone, Darwin's Forgotten Defenders : The Encounter between Evangelical Theology and Evolutionary Thought (Grand Rapids, Mich.: W.B. Eerdmans, 1987), Jon H. Roberts, Darwinism and the Divine in America : Protestant Intellectuals and Organic Evolution, 1859-1900 (Madison, Wis.: University of Wisconsin Press, 1988), Cynthia Eagle Russett, Darwin in America. The Intellectual Response 1865-1912 (San Francisco, CA: W.H. Freeman and Company, 1976), chapter 2.

${ }^{11}$ Don O'Leary, Roman Catholicism and Modern Science. A History (New York: Continuum, 2006), 47; Mariano Artigas, Thomas F. Glick, and Rafael A. Martínez, Negotiating Darwin: The Vatican Confronts Evolution, 1877-1902 (Baltimore: Johns Hopkins University Press, 2006), 5, 6, 281-283.

\footnotetext{
${ }^{12}$ Mariano Artigas, Thomas F. Glick, and Rafael A. Martínez, "Darwin and the Vatican: The Reception of Evolutionary Theories," in The Reception of Charles Darwin in Europe, edited by Eve-Marie Engels and Thomas F. Glick (London: Continuum, 2008), 429, Mariano Artigas, Thomas F. Glick, and Rafael A. Martínez, Negotiating Darwin, 279.
} 
${ }^{13}$ Artigas, Glick, and Martínez, Negotiating Darwin, 270.

${ }^{14}$ R. Scott Appleby, "Exposing Darwin's "Hidden Agenda": Roman Catholic Responses to Evolution," in Disseminating Darwinism. The Role of Place, Race, Religion, and Gender, edited by Ronald L. Numbers and John Stenhouse (Cambridge: Cambridge University Press, 1999), 198.

${ }^{15}$ Barry Brundell, "Catholic Church Politics and Evolution Theory, 1894-1902," The British Journal for the History of Science 34, no. 01 (2001): 81-95, Artigas, Glick, and Martínez, Negotiating Darwin, 27.

${ }^{16}$ Artigas, Glick, and Martínez, "Darwin and the Vatican", Artigas, Glick, and Martínez, Negotiating Darwin, Brundell, "Catholic Church Politics and Evolution Theory, 1894-1902."

${ }^{17}$ O'Leary, Roman Catholicism and Modern Science. A History, 47, Artigas, Glick, and Martínez, "Darwin and the Vatican", 417, Artigas, Glick, and Martínez, Negotiating Darwin, 21-23.

${ }^{18}$ ibidem, 23.

${ }^{19}$ Brundell, "Catholic Church Politics and Evolution Theory, 1894-1902", 82: “[M]odernism took many forms depending on the perceptions of its various opponents, so that the meaning of the term became very imprecise and came to be applied to any and every suspected or alleged deviation from accepted orthodoxy."

${ }^{20}$ O'Leary, Roman Catholicism and Modern Science. A History, 114.

${ }^{21}$ Harry W. Paul, "Religion and Darwinism: Varieties of Catholic Reaction," in The Comparative Reception of Darwinism, edited by Thomas F. Glick (Chicago: University of Chicago Press, 1988), 412.

${ }^{22}$ O'Leary, Roman Catholicism and Modern Science. A History, 117.

${ }^{23}$ Raf De Bont, Darwins Kleinkinderen : De Evolutietheorie in België 1865-1945 (Nijmegen: Vantilt, 2008), chapter 9 .

${ }^{24}$ Appleby, "Exposing Darwin's "Hidden Agenda", 178.

${ }^{25}$ O'Leary, Roman Catholicism and Modern Science. A History, 102, Artigas, Glick, and Martínez, Negotiating Darwin, 159. 
${ }^{26}$ O'Leary. Roman Catholicism and Modern Science. A History, 99.

${ }^{27}$ Artigas, Glick, and Martínez, Negotiating Darwin, chapter 4.

${ }^{28}$ Ibidem, Artigas, Glick, and Martínez, "Darwin and the Vatican.", 426-428.

${ }^{29}$ Pietro Corsi and Paul J. Weindling, "Darwinism in Germany, France, and Italy," in The Darwinian Heritage, edited by D. Kohn (New Jersey: Princeton University Press, 1985), 725-26.

${ }^{30}$ Livingstone, "Science, Region, and Religion."

${ }^{31}$ Don O'Leary, "From the Origin to Humani Generis: Ireland as a Case Study," in Darwin and Catholicism. The Past and Present Dynamics of a Cultural Encounter, edited by Louis Caruana (London: T\&T Clark, 2009), 16, 22.

${ }^{32}$ De Bont, Darwins kleinkinderen, 43.

${ }^{33}$ Silence was also the predominant reaction among French Catholics, including Catholic scientists. As such, their attitude can be better explained as taking part in a general French reaction in which evolution was simply ignored as being too speculative. See Robert E. Stebbins, "France," in The Comparative Reception of Darwinism, edited by Thomas F. Glick (Chicago: University of Chicago Press, 1988), 117-63. In France too, however, Catholic antievolutionary sentiments were fuelled by the anticlerical, materialist and atheist mode evolutionists presented their ideas . See Harry W. Paul, The Edge of Contingency. French Catholic Reaction to Scientific Change from Darwin to Duhem (Gainesville: University Presses of Florida, 1979).

${ }^{34}$ Ilse N. Bulhof, "The Netherlands," in The Comparative Reception of Darwinism, edited by Thomas F. Glick (Chicago: University of Chicago Press, 1988), 269-306.

${ }^{35}$ Bart Leeuwenburgh and Janneke Van der Heide, "Darwin on Dutch Soil: The Early Reception of His Ideas in the Netherlands," in The Reception of Charles Darwin in Europe, edited by Eve-Marie Engels and Thomas F. Glick (London: Continuum, 2008), 175-87.

${ }^{36}$ Bart Leeuwenburgh, Darwin in Domineesland (Nijmegen: Vantilt, 2009).

${ }^{37}$ Abraham C. Flipse, "'De Schepping Zou Er Even Wonderbaar Om Zijn.' Geschiedenis Van Het Evolutiedebat in Gereformeerde En Rooms-Katholieke Kring," in Botsen over Het Begin. Bavinck Lezingen 2009, edited by 
Koert Van Bekkum and George Harinck (Barneveld, 2010), 9-22, Abraham C. Flipse, "Between Neo-Thomist Natural Philosophy and Secular Science: Roman Catholic Scientists in the Netherlands, 1900-1950," in Third ICESHS (Vienna: 2008).

${ }^{38}$ Francisco Pelayo, "Darwinism and Paleontology: Reception and Diffusion of the Theory of Evolution in Spain," in The Reception of Charles Darwin in Europe, edited by Eve-Marie Engels and Thomas F. Glick (London: Continuum, 2008), 386-99.

${ }^{39}$ Thomas F. Glick, "Spain," in The Comparative Reception of Darwinism, edited by Thomas F. Glick (Chicago: University of Chicago Press, 1988), 307-45, 334

${ }^{40}$ ibidem, 344.

${ }^{41}$ Appleby, "Exposing Darwin's "Hidden Agenda", 178.

${ }^{42}$ O'Leary, Roman Catholicism and Modern Science. A History, 114.

${ }^{43}$ Paul, The Edge of Contingency. French Catholic Reaction to Scientific Change from Darwin to Duhem.

${ }^{44}$ Saltationism is a theory that posits that evolution is not a gradual process by occurs by drastic changes (“jumps") from one generation to another.

${ }^{45}$ Peter J. Bowler, The Eclipse of Darwinism. Anti-Darwinian Evolution Theories in the Decades around 1900 (Baltimore: Johns Hopkins Press, 1992).

${ }^{46}$ Charles Darwin, On the Origin of Species by Means of Natural Selection : Or the Preservation of Favoured Races in the Struggle for Life (London: John Murray, 1859), 488.

${ }^{47}$ Darwin Correspondence Project Database. http://www.darwinproject.ac.uk/entry-2833/ (letter no. 2833; accessed 7 September 2010)

${ }^{48}$ Artigas, Glick, and Martínez, Negotiating Darwin, 280.

${ }^{49}$ Among the newly established institutions were the Accademia di San Tomasso, founded in 1874, in Italy and the Institut de Philosophie in Leuven, Belgium, established in 1891. In France, new institutions were founded in Paris, Lille, Lyon, Angers, and Toulouse (for the French institutions, see O'Leary, Roman Catholicism and Modern Science, 95). Among the new journals were the review La scienza Italiana, which was published from 1874 to 1891, and the Revue Thomiste, founded in 1891. For an overview, see http://www.newadvent.org/cathen/10746a.htm

${ }^{50}$ Paul, "Religion and Darwinism: Varieties of Catholic Reaction.", 428. 
${ }^{51}$ Before the Société was founded, Belgian Catholics in their response to evolutionary theory, went through "a short but meaningful phase in which evolutionary theory was vehemently belittled" Raf De Bont, "'Foggy and Contradictory': Evolutionary Theory in Belgium, 1859-1945," in The Reception of Charles Darwin in Europe, edited by Eve-Marie Engels and Thomas F. Glick (London: Continuum, 2008), 194.

${ }^{52}$ De Bont, Darwins Kleinkinderen, 51, 135.

${ }^{53}$ De Bont, Darwins Kleinkinderen, 301-304, De Bont, "'Foggy and Contradictory'.", 195.

${ }^{54}$ Flipse, "Between Neo-Thomist Natural Philosophy and Secular Science: Roman Catholic Scientists in the Netherlands, 1900-1950.", Flipse, "'De Schepping Zou Er Even Wonderbaar Om Zijn.' Geschiedenis Van Het Evolutiedebat in Gereformeerde En Rooms-Katholieke Kring."

${ }^{55}$ De Bont, Darwins Kleinkinderen , 265.

${ }^{56}$ De Bont, "'Foggy and Contradictory'. ", 195.

${ }^{57}$ Raf De Bont, "Rome and Theistic Evolutionism: The Hidden Strategies Behind the 'Dorlodot Affair', 19201926," Annals of Science 62, no. 4 (2005), 474-75, 477.

${ }^{58}$ The "Dorlodot affaire" is discussed in full detail by De Bont, "Rome and Theistic Evolutionism: The Hidden Strategies Behind the 'Dorlodot Affair', 1920-1926."

${ }^{59}$ O’Leary, Roman Catholicism and modern science. A history, 133.

${ }^{60}$ De Bont, Darwins Kleinkinderen, 304.

${ }^{61}$ O’Leary, Roman Catholicism and modern science. A history, 139.

${ }^{62}$ Pius XII, "Humani Generis," (1950), http://www.vatican.va/holy_father/pius_xii/encyclicals/documents/hf_pxii_enc_12081950_humani-generis_en.html.

${ }^{63}$ Pawel Kapusta, "Darwinism from Humani Generis to the Present," in Darwin and Catholicism. The Past and Present Dynamics of a Cultural Encounter, edited by Louis Caruana (London: T\&T Clark, 2009), 27-42.

${ }^{64}$ John Paul II, "Truth Cannot Contradict Truth. Address of Pope John Paul II to the Pontifical Academy of Sciences (October 22, 1996) " (1996), http://www.newadvent.org/library/docs_jp02tc.htm. 
${ }^{65}$ International Theological Commission, "Communion and Stewardship: Human persons created in the image of God," (2004),

http://www.vatican.va/roman_curia/congregations/cfaith/cti_documents/rc_con_cfaith_doc_20040723_communi on-stewardship en.html, paragraph 69.

${ }^{66}$ Ibidem, paragraph 70.

${ }^{67}$ Pope Benedict XVI, “Address of his Holiness Benedict XVI to the members of the Pontifical Academy of Sciences" in Scientific insights into the evolution of the universe and of life, edited by Werner Arber, Nicola Cabbibbo and Marcelo Sánchez Sorondo (Vatican City: The Ponifical Academy of Sciences, 2008), xxxiii-xxxv, John Bohannon, "Vatican science conference offers an ambiguous message", in Science 322, no. 5904 (2008): 1038 .

${ }^{68}$ Bohannon, "Vatican science conference offers an ambiguous message", 1038; Christophe Cardinal Schönborn, "Pope Benedict XVI on 'creation and evolution', in Scientific insights into the evolution of the universe and of life, edited by Werner Arber, Nicola Cabbibbo and Marcelo Sánchez Sorondo (Vatican City: The Ponifical Academy of Sciences, 2008), 16

${ }^{69}$ Ibidem, 23.

${ }^{70}$ See for instance, Christophe Kardinal Schönborn, "Fides, Ratio, Scientia. Zur Evolutionismusdebatte," in Schöpfung Und Evolution. Eine Tagung Mit Papst Benedikt Xvi in Castel Gandolfo (Augsburg: Sankt Ulirch Verlag, 2007), 79-98, Christophe Kardinal Schönborn, "Finding Design in Nature," New York Times, July 7 2005, Christophe Kardinal Schönborn, Ziel Oder Zufall? Schöpfung Und Evolution Aus Der Sicht Eines Vernünftigen Glaubens (Freiburg: Herder, 2007). 